\title{
Derrick Hindery. From Enron to Evo. Pipeline Politics, Global Environmentalism, and Indigenous Rights
} in Bolivia. 328 pages. Tucson, Arizona: The University of Arizona Press, 2013.

From Enron to Evo is a long-term study of Enron and Shell's construction of the Cuiabá pipeline in eastern Bolivia, which goes through the middle of the Chiquitano forest. The route of the pipeline affects a population of about 8,000 as well as four critical ecoregions: the Gran Chaco and Cerrado, which are a mixture of grasslands and scattered trees, the Chiquitano dry forest, and the Pantanal wetlands. As could be anticipated, this project was contested by the thirty-four Chiquitano and two Ayoreo communities that live in the area. After years of field research, extensive interviews and document analyses, Dr. Hindery manages to expose the murky ways in which the hydrocarbon industry works in Bolivia. This is an industry where the powerful - mainly multinational oil companies and the Bolivian government - abuse the ecoregions and the indigenous populations that live on them.

The book is divided into eleven chapters, each of which can be read separately as a self-contained essay. The first six chapters describe the Cuiabá situation before the Evo Morales administration (1985-2005). In the following four chapters, the author centers his analysis on indigenous mobilization, extractive development, and environmental struggle under the government of Morales. The last chapter concludes by discussing the central arguments advanced in the book and evaluating several prospects for better relations between Indigenous peoples and the other actors involved. 
Dr. Hindery convincingly demonstrates that the Morales administration has continued with some of the "neoliberal" policies of previous administrations, despite its strong rhetoric against capitalism and these types of politico-economic policies. Although the Morales administration raised the state's share of profits from the oil and gas industry, most of the country's natural gas continues to be extracted and exported by transnational corporations.

The author claims that the government of the first indigenous president practices a form of state capitalism in which profits from natural resources (e.g., oil, gas, and minerals) are used to fund domestic development. Like his predecessors of the previous two decades, Morales has used the rhetoric of environmental protection and indigenous rights to justify oil, gas, mining, and road development in indigenous territories and ecologically valuable areas. This practice contradicts Morales' promises of leading the country into a new era of sustainable development. Since he was a presidential candidate, Morales has promised to protect 'Mother Earth' (Pachamama) and to incorporate the indigenous worldview that proposes to "live well" (vivir bien), as (supposedly) opposed to the "capitalist" concept of "living better" (vivir mejor).

The author also asserts that the Morales administration has not respected promises to protect indigenous rights, even though they have been enhanced in the constitution the government managed to enact. Unsurprisingly, the extraction of natural resources has led to increased unrest among the affected indigenous communities. According to the author, the Chiquitanos and Ayoreos have developed a "dynamic pragmatism" to defend the right of self-determination over their lives and territories. Besides direct actions (e.g., marches, blockades, strikes), indigenous peoples have turned to Western legal tools and bargained with the other actors involved (i.e., the national government, multinational oil companies and NGOs).

In the big pipeline business, conservation organizations have played their game too. Dr. Hindery describes how Enron and Shell gave US\$20 million to five American and Bolivian conservation groups to greenwash their project, leaving indigenous communities out of the deal. The support of the conservation groups helped to convince the US government to provide funding to the project. 
The book also traces the international support that multinational corporations have enjoyed working in Bolivia. Dr. Hindery shows how the World Bank, working in alliance with the US government, transnational corporations and Bolivian governments, triggered partial privatization of Bolivia's oil and gas sector. The privatizations created the structural conditions necessary for Enron, Shell and other transnational oil corporations to enter Bolivia. This intricate relationship between oil companies and powerful third parties also involved the Cuiabá project. To finance the pipeline, Enron and Shell received a \$200 million loan from the US Government-based Overseas Private Investment Corporation (OPIC), an export credit agency.

A conscious reader will notice that throughout the book the author uses a tone of denunciation that may work against the volume's persuasiveness. As the author himself recognizes (16), he is an environmental advocate, and his activism seems to frame his work. In some parts, the author makes certain assertions that are not grounded on documents or interviews. For instance, Dr. Hindery tends to describe the indigenous groups as a single actor, without relevant internal divisions. (This is hard to believe, given that in any community there are different views of how to resolve a problem.)

In sum, sometimes it seems as if the author is trying to convince the reader that nothing positive can come from the extraction of natural resources in Bolivia. As described, "pipeline politics" certainly entails abusive businesses that have led to environmental and human exploitation. However, given that the hydrocarbon industry is one of the main sources of the state's revenues, governments of all political colors will continue to develop gas and oil projects to fund their policy goals. Therefore, the main question to solve is how to achieve a sustainable development, while minimizing the environmental costs and protecting the rights of the indigenous communities affected by the extractive industry.

From Enron to Evo is certainly a courageous volume that makes a significant contribution for scholars, policymakers, activists and others who want to understand in detail how "pipeline politics" works in Bolivia. The author compellingly disentangles a game that involves highly powerful actors and that touches the heart of the present development model in Bolivia. In an era filled with notorious examples of resource extraction from indigenous territories in Latin America, it seems of the 
utmost relevance to understand how the extractive industry continues to work while causing damage to the environment and local communities.

Ignacio Arana

University of Pittsburgh

\section{(cc) $\mathbf{E Y}$}

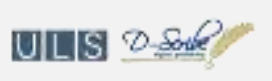

New articles in this journal are licensed under a Creative Commons Attribution 4.0 United States License.

This journal is published by the University Library System of the University of Pittsburgh as part of its D-Scribe Digital Publishing Program, and is cosponsored by the University of Pittsburgh Press. 